\title{
Groundwater characteristics at Seabee Hook, Cape Hallett, Antarctica
}

\author{
ERICA H. HOFSTEE ${ }^{1}$, DAVE I. CAMPBELL ${ }^{1 *}$, MEGAN R. BALKS ${ }^{1}$ and JACKIE AISLABIE ${ }^{2}$ \\ ${ }^{1}$ Department of Earth and Ocean Sciences, The University of Waikato, Private Bag 3105, Hamilton, New Zealand \\ ${ }^{2}$ Landcare Research, Private Bag 3127, Hamilton, New Zealand \\ *corresponding author: davec@waikato.ac.nz
}

\begin{abstract}
Seabee Hook is a low lying gravel spit adjacent to Cape Hallett, northern Victoria Land, in the Ross Sea region of Antarctica and hosts an Adélie penguin (Pygoscelis adeliae) rookery. Dipwells were inserted to monitor changes in depth to, and volume of, groundwater and tracer tests were conducted to estimate aquifer hydraulic conductivity and groundwater velocity. During summer (November-February), meltwater forms a shallow, unconfined, aquifer perched on impermeable ice cemented soil. Groundwater extent and volume depends on the amount of snowfall as meltwater is primarily sourced from melting snow drifts. Groundwater velocity through the permeable gravel and sand was up to $7.8 \mathrm{~m} \mathrm{day}^{-1}$, and hydraulic conductivities of $4.7 \times 10^{-4} \mathrm{~m} \mathrm{~s}^{-1}$ to $3.7 \times 10^{-5} \mathrm{~m} \mathrm{~s}^{-1}$ were measured. The presence of the penguin rookery, and the proximity of the sea, affects groundwater chemistry with elevated concentrations of salts $\left(1205 \mathrm{mg} \mathrm{L}^{-1}\right.$ sodium, $332 \mathrm{mg} \mathrm{L}^{-1}$ potassium) and nutrients (193 $\mathrm{mg} \mathrm{L}^{-1}$ nitrate, $833 \mathrm{mg} \mathrm{L}^{-1}$ ammonia, $10 \mathrm{mg} \mathrm{L}^{-1}$ total phosphorus) compared with groundwater sourced away from the rookery, and with other terrestrial waters in Antarctica.
\end{abstract}

Received 10 February 2006, accepted 11 September 2006

Key words: groundwater chemistry, ice cement, Latitudinal Gradient Project, Victoria Land

\section{Introduction}

Liquid water in terrestrial Antarctica generally occurs as a result of melting from a previously frozen water source. Coastal regions are warmer and have higher precipitation than inland areas, resulting in greater meltwater generation (Holdgate 1977). Meltwater sources on land in coastal areas include glaciers, snow drifts, and ground ice. Liquid water is critical for biological and other soil forming processes, therefore warmer and wetter coastal regions of Antarctica have the potential for more abundant and diverse flora and fauna (Rudolph 1963, Kennedy 1993), and relatively well developed soils.

Cape Hallett, in northern Victoria Land $\left(72^{\circ} \mathrm{S} 170^{\circ} 16^{\prime} \mathrm{E}\right.$, Fig. 1), is a $36 \mathrm{~km}$ long peninsula formed from a $1740 \mathrm{~m}$ high basalt shield volcano (Mount Geoffrey Markham) (Harrington et al. 1967). Seabee Hook is a spit of land formed near the end of the Cape Hallett Peninsula from basalt debris derived from the nearby cliffs and deposited by strong tidal currents. Seabee Hook has an Adélie penguin (Pygoscelis adeliae (Hombron \& Jacquinot)) rookery and was the site of a USA/NZ base, occupied from 1957-1973. During 2003-2006 remnants of the old base, including a large fuel storage tank, were removed as part of a restoration effort.

Groundwater is often present during the warmer summer months (December/January) at Seabee Hook. Meltwater from ground ice and snow drifts percolates through the permeable soil to form a thin, unconfined, aquifer perched above the ice cement. Groundwater in this form could be expected to occur in a number of coastal areas of Antarctica, but minimal documentation exists.

A similar groundwater system was described at Casey Station in the Windmill Islands, East Antarctica, where groundwater has been identified as a major pathway for contaminant transport (Snape et al. 2001a, 2001b, 2005). At the "Old Casey" site, groundwater was present for 2-3 months during summer with surface runoff occurring only in a few ephemeral streams at Thala Valley and Wilkes Station (Snape et al. 2001a). Trials were conducted on the use of permeable reactive barriers to remove contaminants from the groundwater at Casey Station, as subsurface flow is the main contaminant dispersal mechanism (Snape et al. 2001a). At Cape Hallett hydrocarbons could potentially be mobilized by groundwater since spilled hydrocarbons from the abandoned research station are present in the soil.

Shallow groundwater has also been reported at the Larsemann Hills, East Antarctica, where piezometers were used to monitor subsurface water, and to track nutrient flows into freshwater lakes (Kaup \& Burgess 2002). Ice cement exists at 20-90 cm below the surface in the Larsemann Hills and water collects and flows along the surface of the ice cemented soil. Rising piezometric levels were often recorded over the summer period. The nutrient content of the groundwater increased near the end of summer when the active layer was still growing, releasing salt brines and decaying organic matter at a time when less surface meltwater was available to dilute subsurface waters (Kaup \& Burgess 2002). 


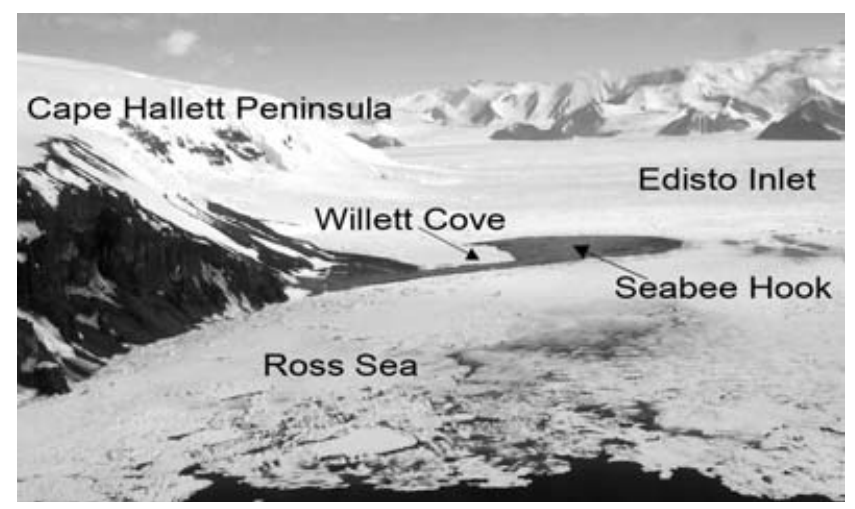

Fig. 1. Key features within the Cape Hallett area (photograph taken on 6 December 2004 looking towards the south-west).

Tracer tests are used to determine groundwater speed and direction and can also be used to determine certain aquifer characteristics, including saturated hydraulic conductivity. Bromide is often used as a tracer in other parts of the world because it is relatively non-reactive with other ions and the porous medium (e.g. Forster et al. 1999, Vanderboroght \& Vereecken 2001, Lin et al. 2003). In the environmentally sensitive coastal Antarctic zone, bromide is a viable option as a tracer, as it occurs naturally within the groundwater at low concentrations and has minimal effect on the environment.

During environmental assessments of the Seabee Hook area in late January and early February 2003, a number of soil pits were excavated and groundwater levels were mapped (unpublished report, Raytheon Polar Services Company 2003). Groundwater was encountered in 15 of 19 soil pits and the thickness of the water layer over the ice cement varied from $<1 \mathrm{~cm}$ to more than $15 \mathrm{~cm}$. A groundwater contour map was constructed of the area, which showed the highest hydraulic heads occurring at the highest elevation, near the old base, and piezometric surfaces sloping away towards the coast. Any pools of surface water were interpreted as surface expressions of the groundwater, rather than being perched above the groundwater. Groundwater was identified as a probable transport mechanism for hydrocarbons, traces of which were found in the soils at some sites.

The soils of the Seabee Hook region have been characterized and mapped by Hofstee et al. (2006). Soils of currently inhabited penguin mounds have a high nutrient status due to guano additions by penguins, while those away from penguin influences are largely unweathered mineral soils (Hofstee et al. 2006).

Meltwater and flooding may affect penguin nesting success. Adélie penguins build nests of stones on elevated sites in order to protect their eggs and chicks from flooding. If meltwater inundates the nests, flooding can lead to nest desertion, egg loss, and subsequent breeding failure (Taylor 1962). Smaller nests are more likely to fail than large nests because of less protection against meltwater (Moreno et al. 1995). Storm waves can also result in nest flooding and reduced breeding success in Humbolt penguins (Spheniscus humboldti Meyen) (Paredes \& Zavalaga 2001). Therefore, the more meltwater present, the more likely it is that nest flooding will occur with consequent reduced breeding success of Adélie penguins.

This paper aims to characterize the extent, duration, and chemical properties of groundwater at Seabee Hook over the 2004-05 summer months, and consider the factors that affect the interannual variability of groundwater occurrence. It is a contribution to the Latitudinal Gradient Project (Howard-Williams et al. 2006).

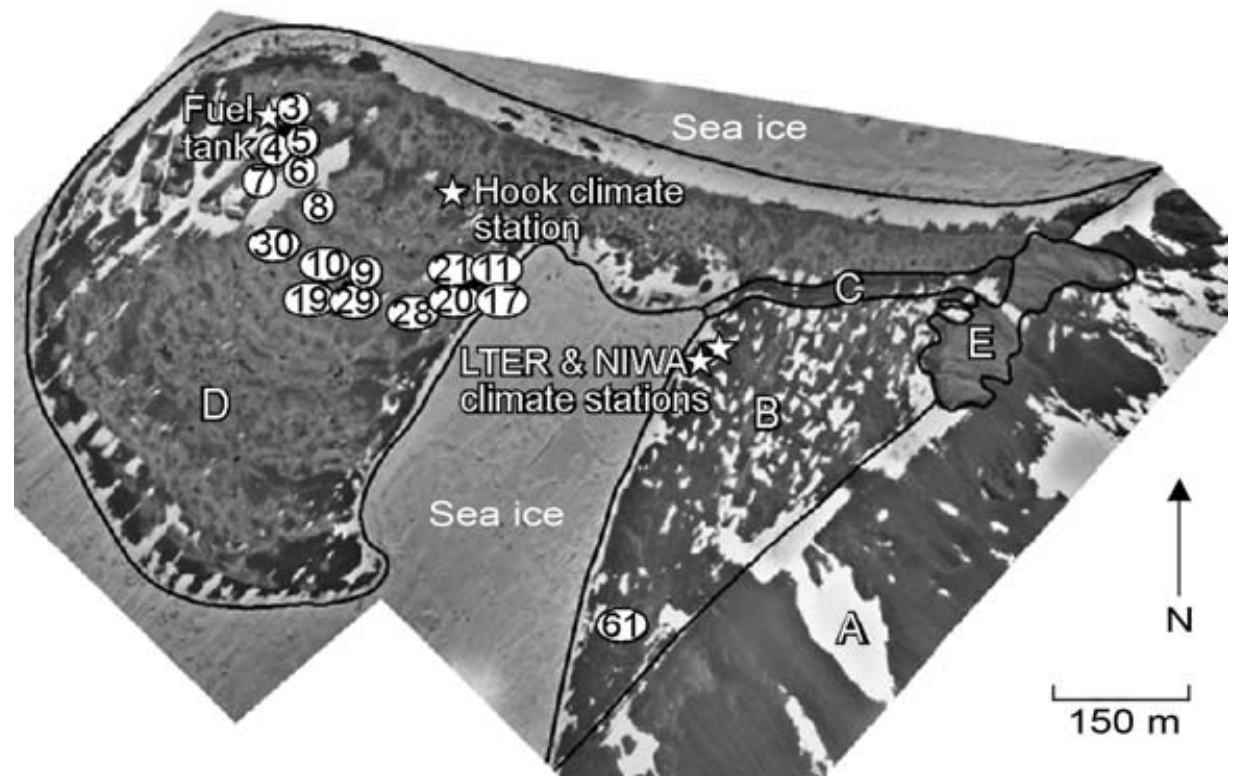

Fig. 2. Aerial photograph of Seabee Hook (summer 1983), showing locations of groundwater monitoring sites (numbered), climate stations and hydrologically distinct areas. A - steep slope, B - wetland area, $\mathrm{C}$ - intermittent stream, D - penguin nesting area on beach ridges, $\mathrm{E}$ - penguin nesting area on scree slope. Buildings near the fuel tank have since been removed and indicate the location of the old Hallett Station. 


\section{Site description and methods}

\section{Hydrological characteristics of Seabee Hook}

Five spatial zones of distinct hydrology were identified at Seabee Hook during the summer months, due to differences in topography and uneven distribution of meltwater sources (Fig. 2).

Area A comprises a steep slope $\left(\sim 30^{\circ}\right)$ which, in the summer of 2004-05, had a number of semi-permanent snow drifts and a small glacier (not shown). The snow drifts and glacier were in direct sunshine for up to 16 hours per day, leading to meltwater generation throughout the summer months. The material on the slope was highly permeable coarse gravel and boulders which allowed rapid subsurface flow of meltwater.

Area B was defined as an area of relict beach gravel and sand deposits beneath the steep slope (area A), which received subsurface flow from the slope, and drained into Willett Cove. The topography of area B is hummocky with some evidence of previous use as a penguin nesting area. However, there are no active nesting sites at present, aside from widely scattered South Polar skua (Catharacta skua maccormicki Saunders) nests on elevated sites. Soils within Area B quickly became saturated during times of high meltwater production, with groundwater rising to form surface ponds and ephemeral streams. The reliable water supply has led to the growth of relatively abundant vegetation consisting of algae, mosses and lichens (Rudolph 1963).

Area C includes an intermittent stream which flowed into Willett Cove from early December 2004 to early February 2005. Meltwater for the stream originated from area A, mostly via ephemeral streams and subsurface flow through area B. Some meltwater flowed directly from area A to the upper reaches of the stream. The stream was often frozen at night when the stream and the steep slope became shaded, and during the day at times of low solar radiation and low air temperature.

Area D comprises the zone currently inhabited by nesting penguins on Seabee Hook. The topography is hummocky with the highest elevation near a large derelict fuel tank (Fig. 2) c. $5 \mathrm{~m}$ above sea level. Area D appeared to have lower volumes of groundwater than areas A, B, and C since snow drifts and ground ice were the only meltwater sources.

Area E comprised a small group of occupied penguin mounds at the base of the steep scree slope. Some meltwater from area A flowed through area E.

This paper will focus on the hydrological characteristics of area D, since this encompasses the majority of the penguin rookery and is the area most strongly affected by past human activities.

\section{Soil climate measurements}

A climate station was installed at Seabee Hook during the
2004-05 season (Fig. 2). Measurements included air temperature and relative humidity at $1.85 \mathrm{~m}$ height (Humitter 50Y, Vaisala, Finland), incoming solar radiation (LI200X, LI-COR, Lincoln, NE, USA), windspeed and wind direction at $2.35 \mathrm{~m}$, (A101M, W200P, Vector Instruments, Clwyd, UK), and soil temperature and moisture at 10, 18 and $32 \mathrm{~cm}$ (Hydra soil moisture probe, Stevens Vitel Inc, Chantilly, Virginia, USA). Data were collected from 8 December 2004 to 24 February 2005 using a datalogger (CR10X, Campbell Scientific), sampling at 10 second intervals and averaged for 30 minute periods. Additional climate data were available from a US Antarctic Programme LTER (Long Term Ecological Research) climate station and a New Zealand NIWA (National Institute of Water and Atmospheric Research) soil temperature monitoring station (Fig. 2). The NIWA station collected soil temperature data using a MRC probe (Measurement Research Corporation, Gig Harbor, WA, USA) and recorded temperature at 10 depths $(5,13,20,28$, 36, 51, 66, 81, 97, and $112 \mathrm{~cm}$ ), averaged for 2 hour periods.

\section{Groundwater monitoring}

Dipwells constructed from $50 \mathrm{~mm}$ diameter polyethylene tubes, slotted through their entire length, were installed to the depth of ice cement $(c .80 \mathrm{~cm})$ along a distinct surface drainage system on Seabee Hook. Soil pits were excavated to the depth of ice cement and dipwells inserted, with the excavations refilled using the original material, repacked at the depth from which it had been excavated. Nine dipwells were installed during the 2003-2004 summer with a further seven installed during the 2004-2005 summer (Fig. 2). Dipwells were monitored for changes in groundwater levels once every two to seven days during the latter part of the 2003-04 summer season and every two days during the 2004-05 summer. At each monitoring time, total depth to ice in the dipwells was assumed to indicate the $0^{\circ} \mathrm{C}$ isotherm (or frost table) depth in the adjacent saturated soil. Dipwells were capped when not in use and during winter.

\section{Tracer tests}

Tracer tests were conducted at Seabee Hook using a pulse injection of $15 \mathrm{~g} \mathrm{~L}^{-1}$ potassium bromide into a dipwell. A network of sampling wells, slotted through their entire length, were located 1-2 m away, downstream from an injection dipwell. Injection of the tracer involved evacuating all of the water in the dipwell using a handpump and immediately pouring the tracer solution into the dipwell, thus minimizing the possibility of a locally high head at the injection point. Sampling was conducted hourly by evacuating around 3-5 times the water volume of each sampling well before the sample was taken. Samples were analysed using a bromide specific electrode $\left(\mathrm{Br}^{-}\right.$ion specific electrode with a Ag. AgCl reference electrode) and a $\mathrm{pH} / \mathrm{ion}$ 
meter (692, Metrohm, Herisau, Switzerland).

Groundwater velocity was calculated from the time delay until the peak bromide concentration was detected in sampling wells during the tracer test,

$$
v=\frac{d}{t}
$$

where

$v=$ groundwater flow velocity $\left(\mathrm{m} \mathrm{s}^{-1}\right)$

$d=$ distance from injection dipwell to sampling piezometer $(\mathrm{m})$

$t=$ time taken for bromide concentration to peak in a sampling piezometer (s)

Hydraulic conductivity was calculated as

$$
K=v \frac{L}{\Delta h}
$$

where,

$v=$ velocity from Eq. 1

$L=$ horizontal distance between injection dipwell and sampling piezometer (m)

$\Delta h=$ change in head between injection dipwell and sampling piezometer $(\mathrm{m})$, determined by leveling survey.

\section{Soil porosity}

Total porosity was estimated by measuring the volume of a sample of soil solids by displacement in water. Porosity was then calculated as the difference between undisturbed soil volume and the volume of solids, expressed as a percentage. The undisturbed sample soil volume was measured by the sand replacement method (Burke et al. 1986), by refilling the excavated area with a known volume of $<2 \mathrm{~mm}$ sand.

\section{Groundwater chemistry analysis}

Groundwater samples were taken from sites 6, 8, 10, 19, 28, 29, and 30 in area D and from site 61 in area B (Fig. 2) using a hand pump, evacuating 3-5 times the water volume of each dipwell before sampling. Samples were filtered within 24 hours of sampling and frozen before being transported to a New Zealand commercial laboratory. Methods described by American Public Health Association (1998) were used to measure soil pH (method 4500-H+B), electrical conductivity (method 2510), total dissolved solids (method 2540 D), total organic carbon (method 5310), calcium, magnesium, potassium and sodium via flame atomic absorption spectrophotometry (method 3111B), inorganic carbon (method $4110 \mathrm{~B}$ ), ammonia, nitrate and reactive phosphorus via flow injection analysis (method 4500 PG). Chloride and total phosphorus were measured following Skougstad et al. (1979) and Hosomi \& Sudo (1986) respectively.
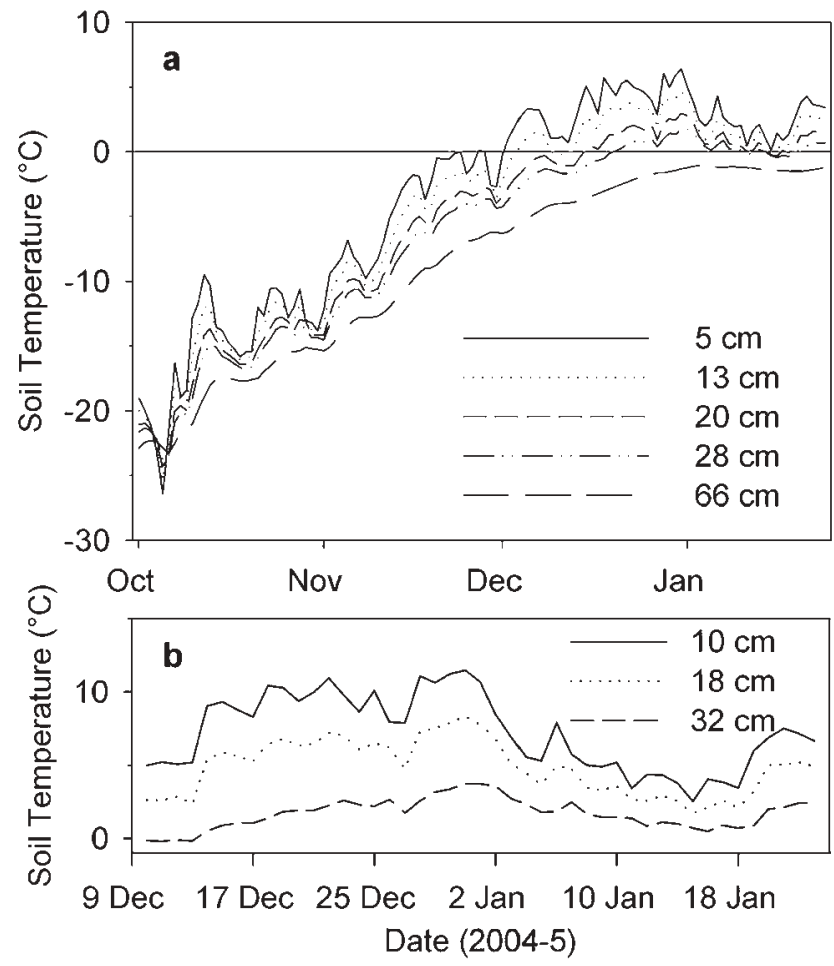

Fig. 3. Average daily soil temperature for various soil depths at Seabee Hook. a. At the NIWA climate station (area B) from early October 2004 to the end of January 2005, and b. at the Seabee Hook climate station (area D) from 10 December 2004-25 January 2005.

\section{Results and discussion}

\section{Spatial and temporal variations in groundwater occurrence}

Groundwater occurrence within area D of Seabee Hook (Fig. 2) varied spatially and temporally. During the 2003-2004 summer surface water was frequently observed whereas it was only present in a small number of ponds during the 2004-2005 summers, presumably as surface expressions of the water-table. The majority of the meltwater was confined to groundwater within the permeable gravel and sand of the low-lying areas (porosity 23-33\%).

Early in the 2004-2005 summer all dipwells were devoid of liquid water, with no groundwater occurring at Seabee Hook. Near surface soil temperatures started to rise above $0^{\circ} \mathrm{C}$ in late November at the NIWA station (Fig. 3a), but groundwater did not start to accumulate in area D until midDecember. During times when shallow soil temperatures were above $0^{\circ} \mathrm{C}$, any meltwater would have evaporated or refrozen when it percolated deeper into the soil. Soil temperatures rose above $0^{\circ} \mathrm{C}$ to a depth of at least $28 \mathrm{~cm}$, at the NIWA site within area B (Fig. 3a) at the end of December 2004. The warmest temperatures occurred in late December coinciding with the summer solstice. At the Seabee Hook climate station soil temperatures were warmer 


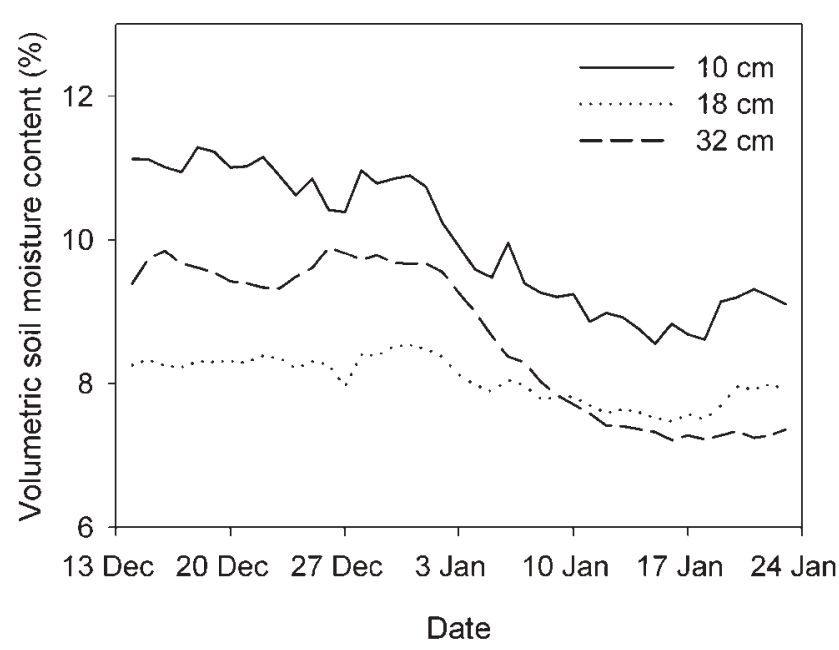

Fig. 4. Volumetric soil liquid moisture content at Seabee Hook climate station from mid December 2004 to the end of January 2005.

than at the NIWA site. Soil at a depth of $32 \mathrm{~cm}$ reached up to $3.7^{\circ} \mathrm{C}$ in late December and early January (Fig. 3b). The differences in temperature at these two sites, which are approximately $300 \mathrm{~m}$ apart, may be attributed primarily to topographic shading. The soil near the NIWA station was in an area shaded for a longer period each night by the Cape Hallett Peninsula, consequently the average depth to ice cement in January 2005 was shallower in area B $(\sim 50 \mathrm{~cm})$ than it was in area $\mathrm{D}(\sim 80 \mathrm{~cm})$.

From early January 2005 soil temperatures began to decrease at both sites (Fig. 3), coinciding with reduced incoming solar radiation as a result of a storm followed by a prolonged period of cloudy days from 2-18 January 2005. When sunny weather returned, soil temperatures increased slightly.

Volumetric soil liquid moisture content ranged from $7-11 \%$ throughout all depths of the soil profile at the Hook climate station and remained relatively constant through the summer, although a slight decrease of $1-2 \%$ in soil liquid moisture content occurred between mid December 2004 and the end of January 2005 (Fig. 4). The accuracy of the soil moisture probes is thought to be $\pm 3 \%$ (Wall et al. 2004), while resolution is clearly better than this. Given that the probes remained undisturbed it is likely that the measured reduction in liquid soil moisture content by $1-2 \%$ from mid December 2004 to end January 2005 occurred. Soil drying from $11 \%$ to $9 \%$ at $10 \mathrm{~cm}$ depth was probably driven by evaporation, while the relatively larger amount of drying at $32 \mathrm{~cm}$, from $10 \%$ to $7 \%$, was probably caused by melting and retreat of ice cement. Soil liquid moisture contents measured at the Seabee Hook climate station were higher than have been recorded for most other soils in the Ross Sea region of Antarctica (e.g. data from Campbell et al. 1997, Wall et al. 2004), reflecting the more northerly coastal setting, warmer temperatures and higher precipitation.
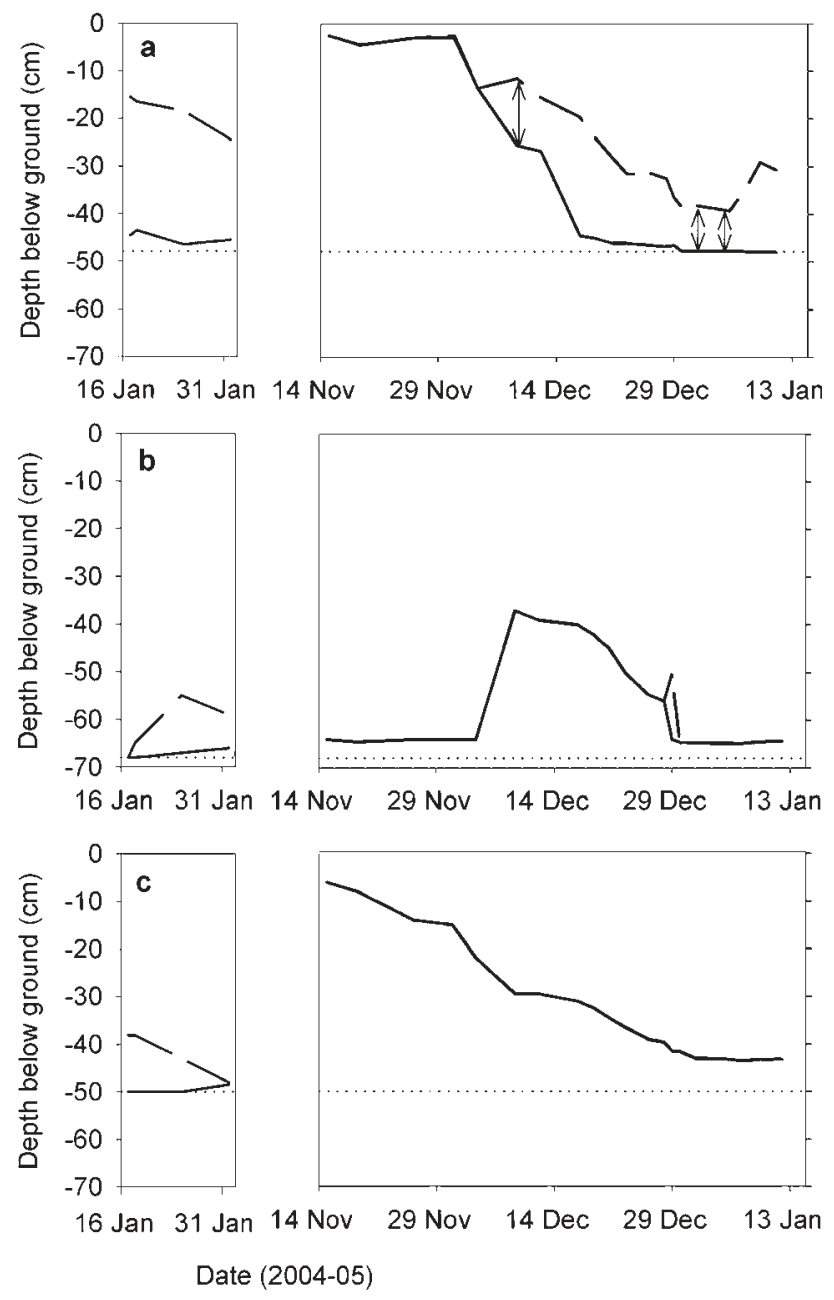

Fig. 5. Depth to water table (long dash) and frost table (solid), during 2003-2004 summer (left) and 2004-2005 summer (right). Dotted horizontal lines indicate base of dipwells a. Site 11 (arrows indicate times of tracer tests and aquifer thickness),

b. Site 3, c. Site 7.

Where soil temperatures were greater than $0^{\circ} \mathrm{C}$, meltwater accumulated to form a shallow perched unconfined groundwater system at Seabee Hook. Depth to frost table increased over the 2004-2005 summer from a minimum of c. $5 \mathrm{~cm}$ below the soil surface in early December 2004 (Fig. 5a), to c. $80 \mathrm{~cm}$ below the soil surface in lateDecember 2004 to early January 2005 (site not shown). The depth to groundwater also increased between early December 2004 and the end of January 2005. The thickness of the saturated zone varied from $<1 \mathrm{~cm}$ to $30 \mathrm{~cm}$ during the 2004-05 summer. In all dipwells the deepest measured frost table level coincided with the bottom of the dipwells (Fig. 5), or close to it. Many of the dipwells accumulated up to $5 \mathrm{~cm}$ of fine material in the bottom between January 2004 and January 2005 and the true frost table level was not recorded (Fig. 5b \& c).

Areas of Seabee Hook with a higher elevation, including penguin mounds and the area near the old base site and fuel 
tank (Fig. 2), had different patterns of depths to ice cement and groundwater compared with intermound areas. No, or very little, groundwater was observed in topographic highs (sites 3, 4, 7, and 9) throughout the 2004-2005 summer. Any meltwater generated within the higher areas may have migrated downslope, or the ice cement present may not have had enough water content to cause saturation of the soil once it melted. In early December 2004 when groundwater was accumulating in the low-lying areas of Seabee Hook (sites 10, 11, 17, 20, 21, 28, 29, 19, and 30) a shallowing of the frost table (by up to $30 \mathrm{~cm}$ within one week) occurred in most areas of higher elevation (e.g. Fig. 5b), including penguin mounds (site 9) and the area near the old fuel tank (sites 3 and 4). The shallowing of the frost table was probably caused by groundwater flowing into an area of frozen but unsaturated soil. Continued increase in soil temperature in December (Fig. 3) led to a subsequent increase in depth to frost table (Fig. 5b), sometimes with the accumulation of a small amount of groundwater. Dipwell 7 had no groundwater recorded during the 2004-2005 summer, and the depth to frost table increased between early December 2004 and late January 2005 (Fig. 5c).

In the 2003-2004 summer groundwater was more extensive than during the 2004-2005 summer, reflecting the interannual variability of this groundwater system. Groundwater was present in all dipwells during the 2003-2004 summer (Fig. 5), but only at low-lying sites between penguin mounds during the 2004-2005 summer. During the 2003-2004 summer a number of storms produced snowdrifts which provided a continual source of meltwater. There were no major snowstorm events during the 2004-2005 summer, leading to less meltwater availability and deeper water table depths.

The depth to groundwater in early February 2004 was often the same as the frost table depth recorded in mid November 2004 (Fig. 5b). However, in some cases the frost

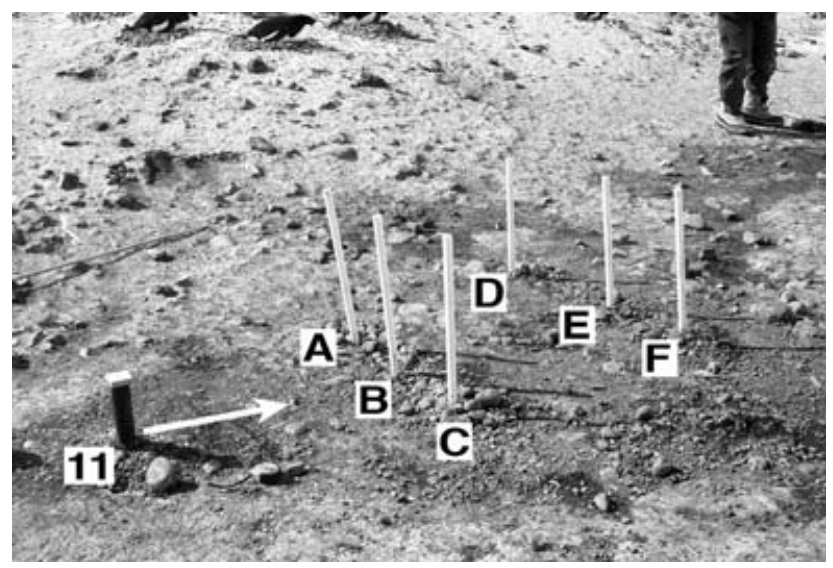

Fig. 6. Photograph of tracer test site, showing the injection well (dipwell 11) and sampling wells A-F. The arrow indicates general direction of groundwater flow. table was shallower in mid-November 2004 than in early February 2004 (Fig. 5a \& c), suggesting a melt event prior to commencement of measurements on 15 November. Soil surface temperature data from the NIWA station indicate that near surface soil temperatures were often $>0^{\circ} \mathrm{C}$ during daytime in early November (data not shown, Fig. 3 shows daily mean temperatures), allowing the possibility of melt from any snow patches remaining after winter.

\section{Groundwater flow characteristics}

Groundwater velocity was estimated using bromine tracer tests near groundwater monitoring site 11 (Fig. 2), at the convergence of two shallow valleys (Fig. 6). Three separate tracer tests (11 December 2004, 3 January and 6 January 2005) were conducted to encompass varying ice cement and groundwater depths.

During the first tracer test on 11 December 2004 a breakthrough curve of bromide concentrations within the sampling wells (Fig. 7a), shows that there were clear peaks of bromide as the tracer traveled downslope within the flowing groundwater.

The breakthrough curves of bromide concentrations in the

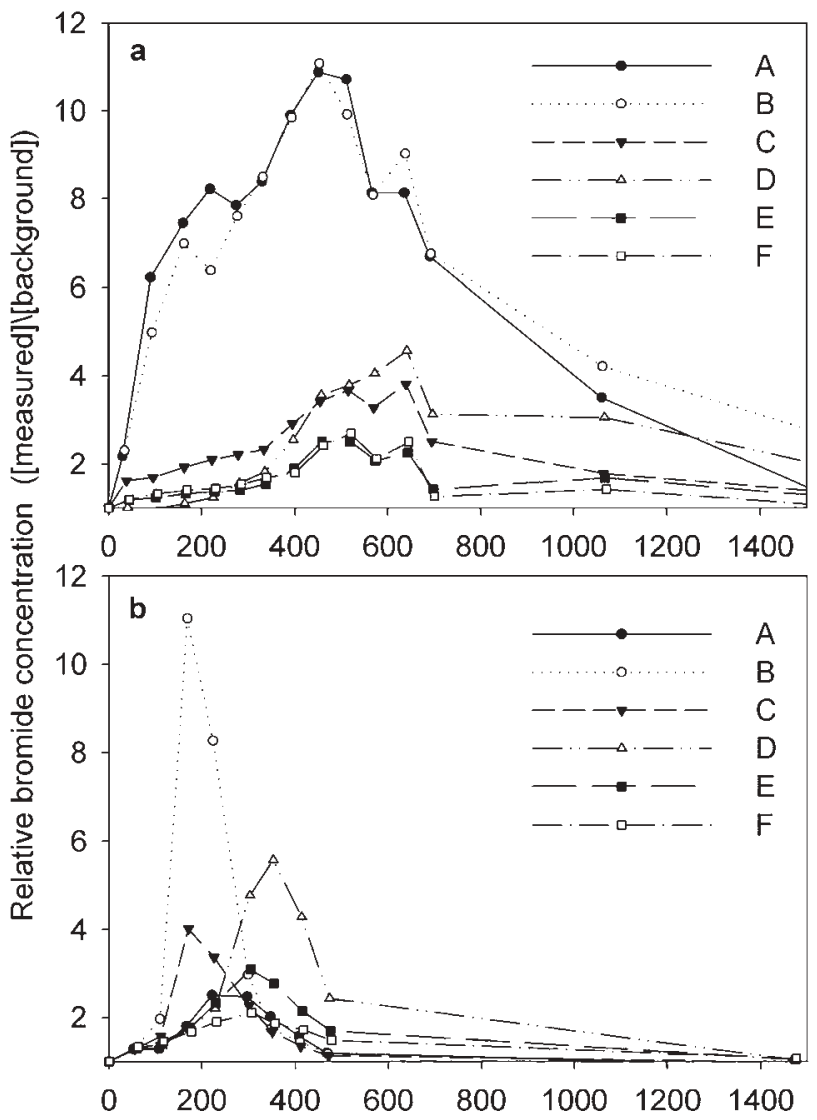

Fig. 7. Breakthrough curves of bromide concentrations in sampling wells near site 11 from tracer tests on a. 11 December 2004, and b. 3 January 2005. 
Table I. Groundwater velocity and aquifer hydraulic conductivity between site 11 and the sampling wells during tracer tests in December 2004 and January 2005.

\begin{tabular}{lccccccc}
\hline Sampling & \multicolumn{3}{c}{ Velocity $\left(\mathrm{m}\right.$ day $\left.^{-1}\right)$} & \multicolumn{3}{c}{ Hydraulic conductivity $\left(\mathrm{m} \mathrm{s}^{-1}\right)$} \\
well & 11 Dec & 3 Jan & 6 Jan & 11 Dec & 3 Jan & 6 Jan \\
\hline A & 3.20 & - & - & $6.3 \times 10^{-5}$ & - & - \\
B & 2.93 & 7.84 & 7.20 & $5.4 \times 10^{-5}$ & $3.6 \times 10^{-4}$ & $3.4 \times 10^{-4}$ \\
C & 2.10 & 7.83 & 7.20 & $3.7 \times 10^{-5}$ & $3.6 \times 10^{-4}$ & $3.3 \times 10^{-4}$ \\
D & 2.09 & 3.79 & 3.54 & $1.0 \times 10^{-4}$ & $4.7 \times 10^{-4}$ & $4.7 \times 10^{-4}$ \\
\hline
\end{tabular}

two January tracer tests were similar, one example is shown in Fig. 7b.

The differences between the tracer test conditions in December 2004, compared with January 2005, were reflected in the different groundwater velocities (Table I), with similar velocities during the 3 January and 6 January 2005 tests (3.79-7.84 $\left.\mathrm{m} \mathrm{day}^{-1}\right)$, and slower groundwater velocities during the 11 December tracer test (2.09-3.2 m day $^{-1}$ ).

On 11 December 2004 groundwater flowed in the layer 10.5-26 cm depth, whereas on 3 and 6 January 2005 the groundwater flowed between 37 and $47 \mathrm{~cm}$ depth (Fig. 5a). Tracer test results indicated hydraulic conductivity of the soil material of the 11 December tracer $\left(3.7 \times 10^{-5} \mathrm{~m} \mathrm{~s}^{-1}\right.$ to $1.0 \times 10^{-4} \mathrm{~m} \mathrm{~s}^{-1}$ ) was lower than the hydraulic conductivity of the soil material of the 3 and 6 January tracer tests (3.3 $\times$ $10^{-4} \mathrm{~m} \mathrm{~s}^{-1}$ to $4.7 \times 10^{-4} \mathrm{~m} \mathrm{~s}^{-1}$ ) (Table I), suggesting soil textural differences. Inter-mound soils typically had higher concentrations of organic matter near the surface than at depth (Hofstee et al. 2006), leading to increased likelihood of blocked soil pores slowing shallow groundwater movement.

During the 11 December 2004 tracer test, the majority of the groundwater flowed towards sampling wells A and B, as can be seen by the largest peaks in Fig. 7a. The smaller peaks in the remaining sampling wells relate to lesser flow past these wells. During the subsequent tracer tests on 3 and 6 January 2005, groundwater levels had dropped (Fig. 5a) and resulted in different flow paths being followed. Flow was initially towards wells $\mathrm{B}$ and $\mathrm{C}$ and no longer towards well A. It is probable that changes in the topography of the ice cement surface dictated the direction of groundwater flow, also reported at Casey Station by Snape et al. (2001a).

A tracer test was also conducted near site 29, however no tracer was picked up in the sampling wells, and it was later found that the hydraulic head sloped away from Willett Cove near site 29 during January 2005. However it is probable that during wet years, there is considerable flow of groundwater towards Willett Cove in broad, shallow valleys, like the valley where site 29 was located.

\section{Groundwater chemistry}

The groundwater within the penguin rookery (area D) generally had a strong dark reddish brown colour (5 YR 3/6) and tended to form froth when disturbed by digging. It had increased salt and nutrient concentrations compared with groundwater sourced away from the rookery (area B) (Table II). Groundwater from the rookery was higher in nutrients, including total phosphorus, (33 times higher) and both ammonia-nitrogen (416 times higher) and nitratenitrogen (7 times higher) than groundwater from area B. Both organic (54 times higher) and inorganic (134 times higher) carbon contents and total dissolved solids (17 times higher) were elevated in the rookery compared with area B.

Salt (sodium, potassium, sulphate, chloride and magnesium) concentrations were also elevated in the rookery while calcium concentrations were similar in both areas. Salt probably originates from guano and penguin nasal excretions (Janes 1997) as well as sea water. Sea water

Table II. Chemistry data for groundwater sampled at Seabee Hook in January 2005 and water chemistry reported from other Antarctic locations. Results from Cape Hallett, Area D are an average of seven samples. All concentrations in $\mathrm{mg} \mathrm{L}^{-1}$ and $\mathrm{EC}$ in $\mu \mathrm{Sm}^{-1}$.

\begin{tabular}{|c|c|c|c|c|c|c|c|c|c|c|c|c|c|c|c|c|}
\hline Location & $\mathrm{pH}$ & EC & TDS* & $\begin{array}{c}\text { Total } \\
\text { C }\end{array}$ & $\begin{array}{c}\text { Inorg. } \\
\text { C }\end{array}$ & $\begin{array}{c}\text { Org. } \\
\text { C }\end{array}$ & $\mathrm{Ca}^{2+}$ & $\mathrm{Mg}^{2+}$ & $\mathrm{Na}^{+}$ & $\mathrm{K}^{+}$ & $\mathrm{Cl}^{-}$ & $\mathrm{SO}_{4}^{2-}$ & $\mathrm{NO}_{3}^{-}$ & $\mathrm{NH}_{3}$ & DRP* ' & $\begin{array}{c}\text { Total } \\
\text { P }\end{array}$ \\
\hline Cape Hallett, Area D & 7.6 & 14000 & 7691 & 622 & 134 & 488 & 18 & 96 & 1205 & 332 & 2653 & 1526 & 193 & 833 & 7 & 10 \\
\hline Standard deviation & & 3402 & 1871 & 106 & 49 & 113 & 10 & 39 & 289 & 100 & 801 & 512 & 115 & 255 & 3.8 & 5 \\
\hline Cape Hallett, Area B & 4.6 & 816 & 450 & 10 & 1 & 9 & 19 & 22 & 85 & 8 & 170 & 38 & 29 & 2 & 0.3 & 23 \\
\hline \multicolumn{17}{|c|}{ King George Island penguin colony: } \\
\hline soil solution ${ }^{\mathrm{a}}$ & 2.9 & 1311 & & & & & 33.2 & 20 & 48 & 37 & & & 140 & & & \\
\hline surface water ${ }^{\mathrm{b}}$ & & & & & & & $5-35$ & $3-20$ & $10-110$ & & & & $0-59$ & & & \\
\hline \multicolumn{17}{|l|}{ Streams in northern } \\
\hline Victoria Land ${ }^{c}$ & $6.4-8.5$ & $41-200$ & & & & & $1.1-8$ & $0.8-3.2$ & $5-10$ & $0.4-8$ & $5.7-30$ & $2-16$ & $0.2-3.4$ & & & \\
\hline Coastal lakes ${ }^{c}$ & 9.2 & 541 & & & & & 23 & 28 & 276 & 16 & 439 & 1.7 & 1.7 & & & \\
\hline Lake Bonney $^{\mathrm{d}}$ & & & & & & & 34-2558 & $21-36272$ & $131-68852$ & $7-2986$ & 244-191044 & $83-5151$ & & & & \\
\hline Lake Hoare $^{\mathrm{d}}$ & & & & & & & $9.2-23$ & $11.6-38$ & 55-184 & 10-31 & 75-239 & 40-109 & & & & \\
\hline Lake Fryxell ${ }^{\mathrm{d}}$ & & & & & & & $22-147$ & $10-371$ & $77-2695$ & $9-196$ & $108-3733$ & 20-206 & & & & \\
\hline Dry Valley streams ${ }^{\mathrm{d}}$ & & & & & & & $1.7-93$ & $0.3-272$ & $0.6-1871$ & $0.3-63$ & 0.8-95 & $0.7-380$ & & & & \\
\hline Dry Valley glaciers ${ }^{\mathrm{d}}$ & & & & & & & $.023-5.3$ & $0.002-0.5$ & $0.03-2$ & $0.004-0.5$ & $0.02-4$ & $0.025-3.1$ & & & & \\
\hline Seawater ${ }^{\mathrm{e}}$ & 8.2 & 40000 & & & & & 412 & 1291 & 10768 & 399 & 19353 & 2712 & & & & \\
\hline
\end{tabular}

a Juchnowicz-Bierbasz \& Rakusa-Suszczewski 2002, ${ }^{\text {b }}$ Tatur \& Myrcha 1983, ${ }^{\text {c }}$ Borghini \& Bargagli 2004, ${ }^{\mathrm{d}}$ Welch et al. $1996,{ }^{\mathrm{e}}$ Chang 1994.

* TDS = Total Dissolved Solids, DRP= Dissolved Reactive Phosphorus which is dissolved inorganic $\mathrm{PO}_{4}$-P measured using the Murphy-Riley reagent. 
is able to mix with groundwater during storms when the effect of breaking waves and high winds can carry large volumes of seawater spray a long distance inland.

The higher nutrient content in groundwater from the rookery is attributed to the water flowing through soil rich in guano, penguin remains, feathers, egg shells and nasal excretions. Nitrate is most probably reduced to ammonia in anaerobic conditions within the soil and groundwater. The high nutrient content is mirrored by the soils in the rookery, where nitrogen, phosphorus and carbon contents were also high (Hofstee et al. 2006).

The chemistry of Antarctic fresh waters has been reported in a number of studies (Table II). Groundwater from outside the rookery had similar chemical properties to other nonornithogenic groundwaters reported in Antarctica. Coastal lakes have been reported to have similar calcium, magnesium, sodium and potassium levels (Borghini \& Bargagli 2004) to groundwater in area B at Seabee Hook. However, sulphate and nitrate levels were higher at Seabee Hook (area B) than in coastal lakes (Borghini \& Bargagli 2004). Streams in northern Victoria Land had lower nutrient and salt concentrations (Borghini \& Bargagli 2004) than the groundwater from area B. Some inland lakes, such as Lake Bonney, have considerably higher salt concentrations (Welch et al. 1996) than area B at Seabee Hook due to concentration by evaporation.

Groundwater chemistry in area D had similarities with groundwater reported under other ornithogenic soils in Antarctica, with nitrate concentrations from Seabee Hook (193 $\mathrm{mg} \mathrm{L}^{-1}$ ) similar to nitrate concentrations in soil solutions from penguin rookeries at King George Island (140 $\mathrm{mg} \mathrm{L}^{-1}$ ) (Juchnowicz-Bierbasz \& Rakusa-Suszczewski 2002). Groundwater from area D is slightly alkaline, whereas the $\mathrm{pH}$ from water at King George Island was reported as 2.9 (Tatur \& Myrch 1983). The concentrations of sodium, potassium, magnesium and also the electrical conductivity were higher in area D at Cape Hallett than those reported from within a penguin rookery at King George Island, possibly due to more sea spray reaching the Seabee Hook area D than the King George Island sample sites. However, these differences could also result from differences in the amount of melt water available from snow, depth of thaw and consequent volume of groundwater flow.

\section{Conclusions}

Five distinct hydrological zones were identified at Seabee Hook, based on topography, fresh water source and degree of penguin influence. Within the present day penguin rookery, summertime melt water from snow drifts percolates into the stony soils to produce a shallow unconfined aquifer perched above ice cemented material. In early summer the frost table may rise as initial meltwater flows into frozen soil at depth, then retreats towards the peak of summer when thawing penetrates to deep soil layers, at a maximum depth of approximately $70 \mathrm{~cm}$.

Groundwater occurrence and volume within the Seabee Hook penguin rookery displays considerable interannual variability, largely depending on the number and size of storms that produce snow packs followed by weather conditions favourable to melting. The summer of 2004-05 was drier than the summer of 2003-04, due to fewer summer snowfall events, and groundwater was of limited spatial extent.

Outside of the penguin rookery, ground and surface waters are sourced from more permanent snow packs on the steep slopes of Cape Hallett Peninsula, which are probably less variable from year to year.

Groundwater flow velocity can be rapid within the penguin rookery at Seabee Hook due to the highly permeable material through which it is flowing, with hydraulic conductivities ranging from $3.7 \times 10^{-5} \mathrm{~m} \mathrm{~s}^{-1}$ to 4.7 $\times 10^{-4} \mathrm{~m} \mathrm{~s}^{-1}$.

The chemistry of groundwater at Seabee Hook shows that concentrations of both salts and nutrients were higher in groundwaters affected by penguin nesting activities compared with a site outside the rookery, and also higher than values reported from other locations in Antarctica.

\section{Acknowledgments}

This research was supported by The New Zealand Foundation for Research Science and Technology, (FRST grant C09X0307) and logistical and additional funding was provided by Antarctica New Zealand including the Antarctica New Zealand LGP postgraduate scholarship. Water chemistry measurements were undertaken by Environmental Chemistry Laboratory (EClab), Landcare Research, Palmerston North, New Zealand.

\section{References}

American Public Health Association. 1998. Standard methods for the examination of water and wastewater, 20th ed. Washington, DC: American Public Health Association, 1085 pp.

Borghini, F. \& BARgagli, R. 2004. Changes of major ion concentrations in melting snow and terrestrial waters from northern Victoria Land, Antarctica. Antarctic Science, 16, 107-115.

Burke, W., Gabriels, D. \& Bouma, J. 1986. Soil structure assessment. Rotterdam: A.A. Balkema, 22 pp.

Campbell, I.B., Claridge, G.G.C., Balks, M.R. \& Campbell, D.I. 1997. Moisture content in soils of the McMurdo Sound and Dry Valley region of Antarctica. In Lyons, W.B., HowARD-Williams, C. \& HAWEs, I., eds. Ecosystem processes in Antarctic ice-free landscapes. Rotterdam: A.A. Balkema, 61-76.

Chang, R. 1994. Chemistry, 5th ed. New York: McGraw-Hill, 994 pp.

Forster, S., Glud, R.N., Gundersen, J.K. \& Huettel, M. 1999. In situ study of bromide tracer and oxygen flux in coastal sediments. Estuarine, Coastal and Shelf Science, 49, 813-827.

Harrington, H.J., Wood, B.L., McKellar, I.C. \& Lensen, G.J. 1967. Topography and geology of the Cape Hallett district, Victoria Land, Antarctica. New Zealand Geological Survey Bulletin, No. 80, 100 pp. 
Hofstee, E.H., Balks, M.R. \& Campbell, D.I. 2006. Soils of Seabee Hook, Cape Hallett, northern Victoria Land, Antarctica. Antarctic Science, 18, 473-486.

Holdgate, M.W. 1977. Terrestrial ecosystems in the Antarctic. Philosophical Transactions of the Royal Society of London Series B, Biological Sciences, 279, 5-25.

Hosomi, M. \& Sudo, R. 1986. Simultaneous determination of total nitrogen and total phosphorus in freshwater samples using persulphate digestion. International Journal of Environmental Studies, 27, 267-275.

Howard-Williams, C., Peterson, D., Lyons, W.B., Cattaneo-Vietti, R. \& Gordon, S. 2006. Measuring ecosystem response in a rapidly changing environment: the Latitudinal Gradient Project. Antarctic Science, 18, 465-471.

JANES, D.N. 1997. Osmoregulation by Adélie penguin chicks on the Antarctic Peninsula. The Auk, 114, 488-495.

Juchnowicz-Bierbasz, M. \& RaKusa-SuszczewsKi, S. 2002. Nutrients and cations content in soil solutions from the present and abandoned penguin rookeries (Antarctica, King George Island). Polish Journal of Ecology, 50, 79-91.

KAup, E. \& Burgess, J.S. 2002. Surface and subsurface flows of nutrients in natural and human impacted catchments on Broknes, Larsemann Hills, Antarctica. Antarctic Science, 14, 343-352.

KENNEDY, A.D. 1993. Water as a limiting factor in the Antarctic terrestrial environment: a biogeographical synthesis. Arctic and Alpine Research, 25, 308-315.

Lin, A.Y.-C., Debroux, J.-F., Cunningham, J.A. \& Reinhard, M. 2003. Comparison of rhodamine WT and bromide in the determination of hydraulic characteristics of constructed wetlands. Ecological Engineering, 20, 75-88.

Moreno, J., Bustamante, J. \& Vinuela, J. 1995. Nest maintenance and stone theft in the chinstrap penguin (Pygoscelis antarctica) 1. Sex roles and effects on fitness. Polar Biology, 15, 533-540.

Paredes, R. \& Zavalaga, C.B. 2001. Nesting sites and nest types as important factors for the conservation of Humbolt penguins (Sphensicus humboldti). Biological Conservation, 100, 199-205.
Raytheon Polar Services Company. 2003. Hallett Station Site Characterisation Report. Raytheon Technical Services Company, Colorado, USA, 50 pp. [Unpublished].

RudolPH, E.D. 1963. Vegetation of Hallett Station area, Victoria Land, Antarctica. Ecology, 44, 585-586.

Skougstad, M.W., Fishman, M.J., Friedman, L.C., Erdmann, D.E. \& DunCAN, S.S. 1979. Methods for determination of inorganic substances in water and fluvial sediments. Techniques of Water-Resources; Investigations of the United States Geological Survey, Book 5, A1, 331-332.

Snape, I., Morris, C.E. \& Cole, C.M. 2001a. The use of permeable reactive barriers to control contaminant dispersal during site remediation in Antarctica. Cold Regions Science and Technology, 32, 157-174.

Snape, I., Riddle, M.J., Stark, J.S., Cole, C.M., King, C.K., Duquesne, S. \& Gore, D.B. 2001b. Management and remediation of contaminated sites at Casey Station, Antarctica. Polar Record, 37, 199-214.

Snape, I., Ferguson, S.H., Harvey, P. \& Riddle, M.J. 2005. Investigation of evaporation and biodegradation of fuel spills in Antarctica: II - Extent of natural attenuation at Casey Station. Chemosphere, 63, 89-98.

TAtur, A. \& Myrcha, A. 1983. Changes in chemical composition of waters running off from the penguin rookeries in the Admiralty Bay region (King George Island, South Shetland Islands, Antarctica). Polish Polar Research, 4, 113-125.

TAYLOR, R.H. 1962. The Adélie penguin Pygoscelis adeliae at Cape Royds. Ibis, 104, 176-204.

VAnderboroght, J. \& VEREeCKen, H. 2001. Analyses of locally measured bromide breakthrough curves from a natural gradient tracer experiment at Krauthausen. Journal of Contaminant Hydrology, 48, 23-43.

Wall, A.M., Balks, M.R., Campbell, D.I. \& Paetzold, R.F. 2004. Soil moisture measurement in the Ross Sea region of Antarctica using hydro soil moisture probes. In Proceedings Supersoil 2004 Conference, Sydney, Australia, December 2004. Sydney: The Regional Institute Ltd.

Welch, K.A., Lyons, W.B., Graham, E., Neumann, K., Thomas, J.M. \& MikeselL, D. 1996. Determination of major element chemistry in terrestrial waters from Antarctica by ion chromatography. Journal of Chromatography, A739, 257-263. 
